DOI: 10.2478/v10141-010-0009-x

\title{
Value Priorities in Connection to Sport Participation
}

\author{
Szilvia Perényi
}

Semmelweis University, Faculty of Physical Education and Sport Sciences, Budapest, Hungary

\section{KEYWORDS}

\begin{abstract}
Sport participation is not only a token for the general physical health of youth and future generations, but also a fundamental element of youth socialisation and value transfer. This study is based on Youth $2004^{\circ}$, which contains a nationwide, randomly selected representative sample of 15 to 29 year old subjects $(\mathrm{N}=8000)$. The purpose of this study was to analyse the layout of value preferences of sport participant and non-participant Hungarian youth by using the same methods of analysis that were applied to the data of the first edition of the Youth research series in year 2000. The goals are to analyse whether similar values would connect to sport participation, taking the time element into consideration, and to review how sport participation is associated with the layout of values, examining the socio-demographic determination of both sport participation and value orientation. For data analysis Mean and non-parametric Mann \& Whitney U test was applied. It was found that, similarly to previous results, the majority of values associated with sport participation fall under the self-direction, stimulation value dimensions of Schwartz (1994). However, the higher importance given to the materialistic value of 'wealth/richness' by the nonparticipants in the first set of data (Perényi 2008), was not traceable four years later. Furthermore, the continuing democratisation of society and sport provided for the inclusion of wider societal segments, which can also be tracked by the wider portfolio of preferred values by sporting participants. Values like appreciation of 'tradition' and 'national identity', however, may also have more association to other socio-demographic factors and, as a consequence, to life circumstances, such as size of settlement or level of education.

value transfer, youth population, sport participation, value preference, societal transition
\end{abstract}

\section{Introduction}

Human actions are comprised of the complexity of morals and values developed and adapted through the socialisation process, starting in early childhood and continuing throughout one's entire life (Deci and Flaste 1995, Andorka 2000). VALUES are what individuals or groups consider 
important (Andorka 2000), and besides, other factors such as individual identity, social status, and lifestyle values are reflected in the everyday activity structure of humans (Giddens 2000). Value research found that human values are influenced by socio-demographic variables and as such, are connected to people's life circumstances (Schwartz 1994, Inglehart 1997). Gender, age, education and other factors such as labour market activity or place of residency, as determining factors, have interconnecting relationships with the life circumstances that people have.

Inglehart (1997) found that people of younger age, whose life is mostly spent with education and under the protective umbrella of parents, give more priority to post-materialistic values as opposed to cohorts of older ages. Having responsibilities for maintaining an independent life or raising children would result in concern for providing for basic physical needs, bringing about a more materialistic life-view. Inglehart (1997) also emphasised the existing differences between genders, as women in general have a more non-materialistic, harmony and religion driven life-view; men, on the other hand, lend more importance to materialistic beliefs, such as wealth, power, and autonomy. Education is also fundamental to developing a more open, critical, and creative life-view; it also enables individuals to occupy better paying jobs and develop more financial security. As a consequence, a higher level of education would also assume a less materialistic or conformity value system and a more self-directive or independent one.

Value change, however, is one that all the different approaches of value research do agree on, specifically, that value changes taking place on the societal level may influence value orientation of people on the individual level (Andorka 2000, Giddens 2000). For example economic or political changes may result in value changes that take place over longer periods of time, such as Hungary's transition from state-socialism to market economy in 1989-1990. Value changes, however, may also be sudden, as a result of fundamental transformations in the life circumstances of individuals, such as getting/losing one's employment, or starting families. Inglehart (1997) found that people's socioeconomic status has a fundamental determination on values pertaining to material well-being. People suffering from financial hardship would demonstrate an enhanced level of priority to materialistic values, such as money, power and security; more comfort in providing for daily needs would show less importance given to these values. Consequently, the materialistic and non-materialistic values are most sensitive to peoples' financial status and security (Inglehart, 1997 and 1977). Schwartz (1994), on the other hand, found the opposite mechanism in relation to self-direction or stimulation values, such as creativity, independence, and an exciting life. In the case of these values, an encouraging environment would upgrade people's priority; for example, they may take more initiatives and come up with independent solutions. However, individuals would downgrade the importance given to these values if the pursuit of them were blocked. Schwartz and Bardi (1997) supported these findings with their research conducted in Eastern-bloc countries, stating that in former state-socialist countries the priority given to self-direction values was lower and conformity, power and security values were higher than in 'West-European' countries.

\section{The sport element}

Research conducted in relation to sport participation found that it also has a strong sociodemographic determination. Scheeder (2005), Wilson (2002), White and Wilson (1999), applying Bourdieu's $(1978 ; 1984)$ theory, stated that a higher place on the societal socio-economic and educational ladder provides for an advantage in sport participation. The sport participation trends of Hungarian youth population follow other national and international trends of findings (Skille 2005, Stempel 2005, Wilson 2002, Fábri 2002, Gáldi 2002, Pluhár et al. 2003), as in Hungary also men, younger age groups, students, the more educated, and the inhabitants of bigger settlements show 
higher participation rates in sporting activities. Consequently, it is suggested that sport participation in Hungary is strongly influenced by the socio-demographic position of individuals. This phenomenon became more characteristic as Hungary entered its new era of market economy; social inequality has widened and the distinction, stated by Bourdieu (1984), became more revealing among individuals.

Research, on the other hand, also shows that childhood and adolescent participation in organised sports increases the possibility of continued physical activity; it functions as a predictor for continued physical activity in later life periods (Vanreusel et al. 1993, Perkins et al. 2004). So, early participation can be considered as a key to building physical activity into the everyday activity program of an individual, which suggests that socialisation through sport also is a substantial element. Sport as one of the social institutions, with its content and its structure, is a platform for the process of socialisation by projecting its own values onto sport participants. The sporting activity is placed in a certain environment, played according to certain written and unwritten rules and led by certain personnel (Coakley 1993). Within its boundaries, a certain value system is in place, purposely projecting positive values such as fair play, winning, strength, health, integrity, pride, etc., but of course it has shortcomings such as cheating, aggressiveness, violence, or unfair advantage because of drug usage. Sporting participants are exposed to this communication and the effects are dependent on the recipients' capability of adapting these messages (Coakley 1993).

According to Schwartz (1994) the value transition moves in two directions; that also holds true in the case of sports. It is like a living organism, communicating within and outside of its own boundaries, sending messages to its surroundings and receiving effects from the outside society. Individuals having the habitus compatible with sport would have a greater likelihood of becoming engaged in sports. Also those who would like to acquire the benefits of sport would accept the value system of sport in order to gain inclusion and benefit from value transfer effects.

Research analyzes value-transition both within sports and outside of sports. More research is conducted that examines the values within organised sporting environments pertaining to competition sport participants, while fewer studies refer to sporting activity on the leisure level. In organised sports, the effects on participants' values revealed positive changes in fair play, helpfulness, and human relations (Dubois 1986, Bredemeier \& Schilds 1993). However, the enhancement of aggressiveness and antisocial behaviour has also been reported as a negative effect (Coakley 1993). A proof of the durability of these value preference changes is not available as no such longitudinal research has been conducted.

The value-transmission power of sport is rarely researched in relation to core human values of society. These studies compare athletes with non-athletes and most of them do not recognize the effect of sport to be strong enough to record differences between the two groups. Research conducted among 16-18 year old German youth found no differences in the level of importance of values between athletes and non-athletes, except in the hierarchical order of values (Mielke \& Bahlke, 1995). Other studies emphasize the power of organised sport and physical activities in the socialisation of the young generation (Pluhár et al. 2003, Aszmann 1997, Perényi 2005), clearly stating differences between the two sub-groups, as children participating in regular organised sports valued friendship and interpersonal relationships significantly higher than the non-participants.

The analysis of data received from the first edition of the Youth research series ${ }^{1}$ of Hungary, found that youth participating in sports gave higher priority to values such as friendship, creativity,

\footnotetext{
${ }^{1}$ Youth $2000^{\odot}$ and Youth $2004^{\odot}$ a central government funded comprehensive research series conducted among the Hungarian youth (15-29 years of age) by the top Hungarian social science institutions and top Hungarian social scientists. The research was conducted under the leadership of the National Institute for Youth Research
} 
and diverse and exciting life; and lower priority to materialistic values, such as money and power, in comparison to non-sport participants (Perényi 2008 and 2010) ${ }^{2}$. Differences of value preferences of sport participants and non-participants were clearly stated; furthermore, they were tracked along the socio-demographic variables. It was found that sport participation also bears a strong relation to sociodemographic variables. However, the direction of cause and effect between sport participation and value orientation could not be clarified.

\section{Societal transition}

The political and economic changes taking place after 1989-1990 in Hungary resulted in a deep societal transition as well as turbulence in the consideration of values (Bauer, 2002). The changes that were noticeable by everyone in their daily life routines and detectable on the individual level were also operationalisable and measurable on the societal level.

The primary analysis of the data received from the research conducted 10 years after the changes in Hungary (Youth 2000 and 2004) has described the value orientation and also sport participation of youth (Bauer 2002, Fábri 2002, Bauer \& Szabó 2005). At the turn of the Millennium, Bauer (2002) stated that the value orientation of Hungarian youth was rather individualistic. The values prioritised by young people were the non-materialistic values, which were followed by the materialistic values; and the lowest priorities were given to values related to societal and national attributes. The sport participation rates demonstrated by the Hungarian youth population are critically low (Fábri 2002, Perényi 2008); they were one of the lowest (33\%) among the countries of the European Union (Hartmann-Tews 2006).

The four years between 2000 and 2004 emphasise the transitional period of the country, as the value preferences showed major changes in the value hierarchy (Bauer and Szabó 2005). The values related to self-direction (e.g. creativity, true friendship), described by Schwartz (1994), received further priority, which, according to Schwartz and Bardi (1997) can be explained by the increasing opportunities, and more room for democratic expression of opinion. Also, the value of 'tradition' received a higher priority in the hierarchy. Materialistic and security values, however, sank to the lowest third of the value structure, which in accordance with Inglehart's theory (1991) is a natural reaction to the economic rise temporally experienced by Hungary within the examined period (Bauer and Szabó 2005). In terms of sport participation the data showed a promising $8 \%$ increase, which was noticeable alongside the ranges of all socio-demographic variables, suggesting a start of democratisation in sport for all segments of society during the time period in question.

\section{Objectives}

The purpose of this study was to analyse the layout of value preferences of sport participant and non-participant Hungarian youth by using the same methods of analysis that were applied to the data of the first edition of the Youth research series in year of 2000. The goals are to analyse whether similar values would connect to sport participation, taking the time element into consideration, and to

(Mobilitas), co-partners were institutions such as the Central Statistic Agency, the Institute of Sociology for the Hungarian Academy of Sciences, the Institute of Political Sciences for the Hungarian Academy of Sciences, the Institute of Educational Research, the Foundation of Century Ending Political School. It has been funded by the Ministry of Youth and Sports and the Prime Ministers' Office, Ministry of Work and Social Affairs

${ }^{2}$ Analyse of data received in Youth $2000^{\circ}$. 
review, how sport participation is associated with the layout of values, examining the sociodemographic determination of both sport participation and value orientation.

This research series provided a unique opportunity to follow the values connected to youth regularly participating in sports. However, since another set of cross-sectional data was provided here, longitudinal changes cannot be proved during the given time period. However, the data can show trends of change that youth generations demonstrate having spent four years in Hungary's political, economic, and societal transition. On the basis of the above, in relation to human values and sport participation, a similar study has never before conducted. It is also assumed that in the year 2004 there will be differences between sport participants and non-participants with regard to the same values found in the previous analysis; however, the value changes recorded since 2000 , as well as the sociodemographic variables, will have effects on the layout of the value-preferences of this study.

\section{Methods}

This study is based on Youth $2004^{\circ}$, which contains a nationwide, randomly selected representative sample of 15 to 29 year old subjects $(\mathrm{N}=8000)$. Requirements for representativeness were met in relation to age, gender, type of settlement and municipality of residency.

This research series provides a complex analysis of all life aspects of Hungarian youth, including education, family background, economic status, labour market position, political affiliation, values and beliefs, cultural and leisure activities, including sport participation. The measurement of sporting habits and value orientations have been incorporated as separate chapters, eliminating answer automatism and answer expectations. Subjects were examined by questionnaire-based personal interviews conducted by professional agents. The instrument contained open and closed questions.

Questions measuring the importance of general human values listed 19 values $^{3}$ evaluated on a scale of 1-5, where numerical digits were ascribed the following meanings: $1=$ not important at all, 5 $=$ very important 2,3 , and $4=$ interim grades. Data received on the preference of the listed human values were accepted as independent variables. The chosen dependent variables had the following ranges: gender (men, women); age group (15-19, 20-24, 25-29 years); education (low, middle, high) ${ }^{4}$, size of settlement (capital, county towns, towns, villages) and labour-market activity (student, employed, unemployed).

This study is a second analysis of YOUTH $2004^{\circ}$, using SPSS 15.0 version. Statistical Analysis included 'mean', to demonstrate the structural hierarchy of values; and the non-parametric Mann \& Whitney $U$ test to compare the strength of importance given to values. In this analysis, the sample was divided into two sub-samples: sport participants and non-participants ${ }^{5}$ who were compared with regard to their preferences of core human values (Tenenbaum 2005).

\footnotetext{
${ }^{3}$ Human values measured on a Likert-scale of 5: family security, peace, inner harmony, power, traditions, love, beauty, social order, religion, true friendship, creativity, interesting life, diverse life, wealth/richness, national identity, freedom; only in data from 2004: unity with nature, courtesy, decision-making rights.

${ }^{4}$ Low education level $=$ completed elementary school. Medium education level= completed high school, vocational school. High education level= completed college and university with Bachelor, Master's or PhD degrees.

${ }^{5}$ Sport participation is defined as a 'yes' answer to the question "Do you do any sporting activity outside of physical education classes?" Non-participants answered this question with a 'no'.
} 


\section{Results}

\section{Analysis of value preferences}

In the analysis of value preferences the two sub-groups, sport participant and non-participant, have been compared with each other, taking two approaches in the analysis: on the one hand, the importance given to human values, based on the calculated 'mean', has formulated a hierarchical structure of values; on the other, the strength of importance was measured by 'mean rank' scores gained from the non-parametric Mann \& Whitney test, which provided a base for tracking the differences between the two sub-groups along the ranges of socio-demographic variables (Tenenbaum 2005).

\section{Hierarchy of values}

The hierarchy of values (based on 'mean') showed hardly any difference between the two subgroups (Table 1.), as only two of the values changed order by two or more rank positions ${ }^{6}$. In the first third of the value structure, the hierarchy of the values has not changed at all. A difference in the hierarchy of values was only found in the middle part of the value structure. The importance given to the value of 'interesting life' rose among sport participants as the value's place of order changed from $12^{\text {th }}$ place to $10^{\text {th }}$. This change was also accompanied by a 0.19 point raise in the 'mean' given to this value. The opposite is recorded regarding the value of 'tradition'; it remained behind by two places of order in the hierarchy; however, the strength of consideration has grown by 0.06 point (Table 1 ).

Table 1. Hierarchy of values sport participants and non-participants ('mean' rank) in Youth2004 ${ }^{\circ}$. $(\mathrm{N}=7785)$

\begin{tabular}{|c|c|c|c|c|c|}
\hline & $\begin{array}{l}\text { non-part. } \\
(\mathrm{N}=4443)\end{array}$ & & & $\begin{array}{l}\text { sport part. } \\
(\mathbf{N}=\mathbf{3 1 6 5})\end{array}$ & \\
\hline 1. & family safety & 4,80 & 1. & family safety & 4,83 \\
\hline 2. & love & 4,76 & 2. & love & 4,77 \\
\hline 3. & peace & 4,66 & 3. & true friendship & $4,76^{*}$ \\
\hline 4. & true friendship & 4,64 & 4. & peace & 4,66 \\
\hline 5. & inner harmony & 4,60 & 5. & inner harmony & 4,64 \\
\hline 6. & freedom & 4,48 & 6. & freedom & 4,55 \\
\hline 7. & courtesy & 4,33 & 7. & courtesy & 4,40 \\
\hline 8. & unity with nature & 4,03 & 8. & unity with nature & $4,16^{*}$ \\
\hline 9. & creativity & 3,96 & 9. & creativity & $4,15^{*}$ \\
\hline 10. & tradition & 3,88 & 10. & interesting life & $4,00^{*}$ \\
\hline 11. & diverse life & 3,82 & 11. & diverse life & $3,99 *$ \\
\hline 12. & interesting life & 3,81 & 12. & tradition & 3,94 \\
\hline 13. & beauty & 3,80 & 13. & beauty & 3,88 \\
\hline 14. & social order & 3,73 & 14. & decision-making rights & $3,85^{*}$ \\
\hline 15. & decision-making rights & 3,65 & 15. & social order & 3,79 \\
\hline 16. & wealth & 3,68 & 16. & national identity & $3,70^{*}$ \\
\hline 17. & national identity & 3,54 & 17. & wealth & 3,64 \\
\hline 18. & religion & 2,96 & 18. & religion & 3,01 \\
\hline 19. & power & 2,59 & 19. & power & 2,67 \\
\hline
\end{tabular}

It must be noted that only one of these values, 'tradition', was among those values whose position has also changed on the societal level during the first four years of the new millennium (Bauer 2002). Societal changes of value trends between 2000 and 2004 for self-direction values, however, were reflected in the value preferences of sport participants as the priority for an 'interesting

${ }^{6}$ Change in the hierarchy only accepted if the value has raised or reduced its place of order by two or more places (Bauer, 2002) 
life', which has climbed in hierarchy among sport participants; furthermore, it also received a significantly higher 'mean' $(4,00, \mathrm{p}<.001)$ for sport participants as opposed to the total population (3.89). With regard to the value of 'tradition', opposite changes were recorded among sport participants in comparison to the total population in 2000. It became lower in the hierarchy, but also, the 'mean' given by sport participants (3.94) was not significantly different from that given by the total population (3.90). More information is expected to be revealed during the analysis of the strength given to the values by the sub-groups.

Table 2. Value preferences of sport participants and non-participants ('mean' rank) in Youth2004 ${ }^{\circ}$.

\begin{tabular}{lll}
\hline value item & non-part. & sport part. \\
& $\mathbf{N}=\mathbf{4 4 4 3}$ & $\mathbf{N}=\mathbf{3 1 6 5}$ \\
\hline inner harmony & 3779,94 & 3838,98 \\
power & 3742,42 & $3891,65^{* *}$ \\
freedom & 3743,78 & $3889,73^{* *}$ \\
social order & 3768,69 & 3854,77 \\
interesting life & 3652,24 & $4018,25^{* * *}$ \\
wealth & $3856,20 *$ & 3731,92 \\
national identity & 3673,66 & $3988,17 * * *$ \\
creativity & 3640,49 & $4034,73^{* * *}$ \\
peace & 3848,98 & 3863,44 \\
tradition & 3782,46 & $3956,67 * * *$ \\
religion & 3823,87 & 3898,63 \\
family safety & 3826,48 & $3894,97 *$ \\
diverse life & 3725,33 & $4036,74^{* * *}$ \\
true friendship & 3724,89 & $4037,35^{* * *}$ \\
love & 3791,73 & $3943,67 *$ \\
beauty & 3839,87 & 3876,21 \\
courtesy & 3752,38 & $3877,66^{* *}$ \\
unity with nature & 3725,67 & $4036,26^{* * *}$ \\
decision-making rights & 3721,03 & $4042,77^{* * *}$ \\
\hline$* \mathrm{p}<0.05 ; * \mathrm{p}<0.01, * * * \mathrm{p}<0.001$ & \\
& &
\end{tabular}

Based on the results gained from the Mann \& Whitney U test, the two sub-groups showed significant differences in most of the values, suggesting that sport participants and non-participants strongly differ in their priorities of core human values. Significant difference was found $(p<.001)$ in the preferences of values such as 'true friendship', 'creativity', 'diverse life', 'interesting life', 'national identity', 'tradition', and; in addition 'unity with nature', and decision-making rights'. Also, significant differences were found $(\mathrm{p}<.01$ in the case of 'power', 'freedom', and 'courtesy'. Furthermore, 'family safety' and 'love' also showed a difference $(p<.05)$. All the above values were considered more important by subjects of the sport participant group. The non-participant group assigned higher importance $(\mathrm{p}<.05)$ only to the value 'wealth/richness', but on a lower level of significance than four years earlier (Table 2.). The change recorded with regard to the value 'wealth/richness' is suggested by the 'mean', by the order in value hierarchy, and also by the 'mean rank' scores. This change could be explained, as an application of Inglehart's theory (1991), by the growth of the economy in Hungary that led to a better provision of fundamental life needs and improving life circumstances during this period. This allowed people to lead a financially more comfortable and secure life that created a base for a lower materialistic focus.

It seems that sport participation moves in parallel with the self-direction values of Schwartz (1994), as was found in the dataset of the year 2000. And the continued democratisation of the country has given more scope for these values to endure on the societal level; the value environment of sport provided further possibilities for enhanced priority by sport participants. The similarly enhanced priority of sport participants given to the value of 'tradition', 'national identity' and 'power' needs 
more exploration and explanation, because four years earlier these values bore no relation to sport participation.

\section{Values vs. socio-demographic factors}

The inclusion of socio-demographic variables in the comparison of the value preferences between sport participants and non-participants also reinforced the previously revealed differences of value orientation between the sub-groups. Also, in the light of understanding sport participation rates, it gave more clarity to the higher priority given by sport participants to values such as 'tradition', 'national identity', and 'power'.

Gender: Significant differences were found $(p<.000)$ between the two sub-groups of both genders. Both men and women who take part in sporting activities gave higher priority to 'interesting life', 'creativity', 'diverse life', 'true friendship', 'unity with nature' and 'decision-making rights'. Also, 'national identity' $(p<.000)$ and 'traditions' $(p<.01)$ were more important for male and female sport participants, so it seems that it is not the gender variable that explains the higher preferences of sport participants. Furthermore, men participating in sports considered 'freedom', 'religion' and 'courtesy' more important in comparison to non-participant men, while sport participant women evaluated 'family safety' as more important.

The higher preference for materialistic values by non-participants, was revealed again similarly to the trends from 2000, along with the gender variable as non-participant men gave higher priority to 'power' in comparison to sport participants, while non-participant women gave higher importance to the value of 'wealth/richness' (Table 3.). These results suggest that the gender trends of values suggested by Inglehart (1991) seemed to be altered in connection to sport participation in both genders. Males, but also females, participating in sport were less materialistic in comparison to nonparticipant males, and females in sport assigned more importance to self-direction values in comparison to non-participant females.

Age: Sport participation was a major factor in the preferences of values in terms of the three age groups as well. Sport participants in all three age groups considered 'interesting life', 'creativity', 'true friendship', 'national identity', and in addition 'unity with nature' and 'decision-making rights' more important. Non-participants have not given more priority to any of the values, except the 24-29 age group, which preferred 'wealth/richness', giving it a higher importance.

The preference for some values appeared in some of the ranges of the age variable, such as the 20-24 year old sport participants, who have assigned more importance to 'inner harmony', 'social order', tradition', family safety', beauty' and courtesy' in comparison to non-participants. Freedom was prioritised by both the 20-24 year old and the 24-29 year old sport participant groups. The higher priority given to the value of 'national identity' ran through sport participant sub-groups of all age groups. Higher preferences for 'tradition' by sport participants, however, were only recorded in the 2024 year old group.

According to Inglehart and Schwartz's theories the increase of age would account for more concern for materialistic and security values and less priority to self-direction and stimulation values. As we see from the data, sport participation gave further reinforcement to self-direction values in all age groups. Preferences for materialistic values showed no difference between the two sub-groups of the 25-29 year olds. So, the subjects of the oldest age group are not only similar in their level of priority for materialistic values, but they also live the most sedentary life style; their participation rate is $12 \%$ below the youngest age group. This shows the interconnection of the increase of life-stage 
responsibilities and enhanced materialistic thinking, which is also matched with reduced participation in sports.

Education: The level of education demonstrated revealing differences between the two subgroups. The values that were given higher priority by sport participants (interesting life, creativity, diverse life, true friendship, courtesy, national identity, and, in addition, unity with nature, and decision-making rights) remained more important among the sport participant sub-group of subjects with a low and middle level of education. However, among subjects with higher education the two sub-groups showed a new pattern, as only a limited number of values showed a difference between the sub-groups. These were 'interesting life' ( $p<0.5$ and 'unity with nature', 'creativity', 'diverse life' $(p<0.1)$. It is interesting to see that individuals with a higher level of education did not differ in the consideration given to the value of 'true friendship'. The reasoning for this could be that a higher level of education provides more life opportunities, more freedom for self expression, and more opportunities for social engagement. In this sense, a higher level of education provides similar life situations to those that a sporting environment secures for people with less cultural capital.

Subjects participating in sports with a low and middle level of education preferred values such as 'power', and 'courtesy'. Sport participants with a low education level have given higher priorities to 'freedom'. 'Traditions' were prioritised by sport participants with a middle level of education. Subjects with a low educational level from the non-sport participant sub-group showed higher priority to only one value: 'wealth and richness' (Table 4.). All these results can be better interpreted with the application of Inglehart and Schwartz's theories. But self-direction value environment in regards to sport participation, broadened with Bourdieu's theory on cultural capital, has a direct relation to the likelihood of participation in sports (51\% of subjects with a high level of education are sport participants in contrast to $35 \%$ of those with a basic level of education). It seems that the preferences of values such as 'power', 'tradition' are attached to the increase of participation demonstrated by subjects with a low and middle education level.

Labour market activity: When considering labour market activity, sport participants among students, the employed and the unemployed share a higher priority given to values of 'creativity', 'diverse life', 'true friendship', 'national identity', 'tradition', 'unity with nature', and 'decisionmaking rights'. All these values were considered more important by the sport participant sub-group, regardless of their position in the labour market. This gives an important result, as all three activity groups represent great differences in their social status, life style, and life opportunities, but similarities in value priorities if participating in sports (Table 4.).

Students and employed subjects participating in sports also gave higher priority to the values of 'freedom' and 'love' in comparison to the non-participant subjects. The importance given to the value of 'interesting life', however, does not seem to show any difference between the two sub-groups of students, which represents similar mechanisms as mentioned before in relation to higher educational level. From the non-participant group, only the employed group showed higher priorities to the value of 'wealth and richness'.

It seems that it is the student life period that mostly provides the opportunity to take part in sports in Hungary, as there is a $14 \%$ decrease as soon as individuals leave the education system and enter the job market. The life circumstances mentioned by Schwartz (1994) in relevance with values, and the economic and cultural capital of Bourdieu (1984) in connection with sport participation are especially apparent when reviewing the inactive group; that is the unemployed, the disabled, or mothers with small children (more materialistic value orientation and $34 \%$ decrease in sport participation in comparison to students). 
Table 3. Value preferences of sport participants and non-participants by gender and age ('mean' rank) in Youth2004 ${ }^{\odot}$.

\begin{tabular}{|c|c|c|c|c|c|c|c|c|c|c|}
\hline \multirow[t]{2}{*}{ values } & & \multicolumn{2}{|l|}{ women } & \multicolumn{2}{|c|}{ 15-19 years } & \multicolumn{2}{|c|}{$20-24$ years } & \multicolumn{2}{|l|}{$24-29$ years } \\
\hline & $\begin{array}{l}\text { non-part. } \\
\mathrm{N}=2016\end{array}$ & $\begin{array}{l}\text { sport part. } \\
\mathrm{N}=1868\end{array}$ & $\begin{array}{l}\text { non-part. } \\
\mathrm{N}=2493\end{array}$ & $\begin{array}{l}\text { sport part. } \\
\mathrm{N}=1288\end{array}$ & $\begin{array}{l}\text { non-part. } \\
\mathrm{N}=1070\end{array}$ & $\begin{array}{l}\text { sport part. } \\
\mathrm{N}=1154\end{array}$ & $\begin{array}{l}\text { non-part. } \\
\mathrm{N}=1429\end{array}$ & $\begin{array}{l}\text { sport part. } \\
\mathrm{N}=977\end{array}$ & $\begin{array}{l}\text { non-part. } \\
\mathrm{N}=2003\end{array}$ & $\begin{array}{l}\text { sport part. } \\
\mathrm{N}=1075\end{array}$ \\
\hline inner harmony & 1903,90 & $1984,16 * *$ & 1855,64 & $1855,64 * ?$ & 1122,27 & 1103,45 & 1165,52 & $1255,62 * * *$ & 1528,52 & 1559,97 \\
\hline power & 1899,08* & 1989,36 & 1894,31 & 1848,17 & 1104,09 & 1120,30 & 1186,39 & 1224,94 & 1524,47 & 1567,51 \\
\hline freedom & 1902,09 & $1986,11 * *$ & 1861,22 & 1911,64 & 1109,67 & 1115,12 & 1178,32 & $1236,80 *$ & 1510,11 & $1594,25^{* *}$ \\
\hline social order & 1930,67 & 1955,27 & 1862,94 & 1908,36 & 1107,41 & 1117,22 & 1168,93 & $1250,60 * *$ & 1524,06 & 1568,27 \\
\hline interesting life & 1848,39 & $2044,07 * * *$ & 1834,86 & $1962,21 * * *$ & 1078,56 & $1143,97 * *$ & 1150,15 & $1278,21 * * *$ & 1483,52 & $1643,81 * * *$ \\
\hline wealth & 1961,35 & 1922,16 & $1913,71 * *$ & 1810,95 & 1116,31 & 1108,97 & 1220,04 & 1175,49 & $1562,46^{*}$ & 1496,72 \\
\hline national identity & 1867,47 & $2023,47 * * *$ & 1827,48 & $1976,39 * * *$ & 1069,76 & $1152,13 * *$ & 1143,59 & $1287,85 * * *$ & 1497,61 & $1617,56 * * *$ \\
\hline creativity & 1829,77 & $2064,16 * * *$ & 1811,04 & $2007,92 * * *$ & 1078,29 & $1144,22 * *$ & 1132,86 & $1303,61 * * *$ & 1469,98 & $1669,04 * * *$ \\
\hline peace & 1924,21 & 1978,46 & 1892,35 & 1888,38 & 1123,87 & 1118,33 & 1190,75 & 1222,15 & 1542,54 & 1540,99 \\
\hline tradition & 1911,90 & $1991,55^{*}$ & 1855,02 & $1960,64 * *$ & 1101,31 & 1139,28 & 1155,66 & $1273,47 * * *$ & 1529,48 & 1565,29 \\
\hline religion & 1905,00 & $1998,89 * *$ & 1888,32 & 1896,19 & 1103,80 & 1136,97 & 1181,60 & 1235,53 & 1548,93 & 1529,10 \\
\hline family safety & 1928,62 & 1973,77 & 1874,82 & $1922,31 *$ & 1113,87 & 1127,62 & 1182,92 & $1233,60 * *$ & 1536,33 & 1552,55 \\
\hline diverse life & 1884,18 & $2021,04 * * *$ & 1842,08 & $1985,68 * * *$ & 1096,25 & 1143,99 & 1158,10 & $1269,91 * * *$ & 1488,91 & $1640,74 * * *$ \\
\hline true friendship & 1855,09 & $2051,97 * * *$ & 1851,75 & $1966,96 * * *$ & 1098,23 & $1142,14 * *$ & 1168,35 & $1254,91 * * *$ & 1495,27 & $1628,91 * * *$ \\
\hline love & 1879,38 & $2026,14 * * *$ & 1892,97 & 1887,20 & 1109,26 & 1131,90 & 1175,28 & $1244,78^{*}$ & 1526,22 & 1571,34 \\
\hline beauty & 1921,57 & 1981,27 & 1888,85 & 1895,15 & 1120,51 & 1121,45 & 1195,25 & 1215,57 & 1533,18 & 1558,41 \\
\hline courtesy & 1872,52 & $2018,02 * * *$ & 1869,10 & 1896,54 & 1106,44 & 1118,97 & 1167,99 & $1251,99 * *$ & 1522,61 & 1570,97 \\
\hline unity with nature & 1882,76 & $2022,54 * * *$ & 1829,99 & $2009,09 * * *$ & 1082,14 & $1157,08 * *$ & 1146,19 & $1287,33 * * *$ & 1498,61 & $1622,70 * * *$ \\
\hline $\begin{array}{l}\text { decision-making } \\
\text { rights }\end{array}$ & 1871,70 & $2034,30 * * *$ & 1834,77 & $1999,83 * * *$ & 1093,83 & $1146,23 *$ & 1151,52 & $1279,52 * * *$ & 1499,68 & $1620,72 * * *$ \\
\hline
\end{tabular}


Table 4. Value preferences of sport participants and non-participants by level of education and economic activity ('mean’ rank) in Youth2004 ${ }^{\odot}$.

\begin{tabular}{|c|c|c|c|c|c|c|c|c|c|c|c|c|}
\hline \multirow[t]{2}{*}{ values } & \multicolumn{2}{|l|}{ low level } & \multicolumn{2}{|l|}{ middle level } & \multicolumn{2}{|l|}{ high level } & \multicolumn{2}{|l|}{ student } & \multicolumn{2}{|l|}{ employed } & \multicolumn{2}{|c|}{ unemployed } \\
\hline & $\begin{array}{l}\text { non-part. } \\
\mathrm{N}=2552\end{array}$ & $\begin{array}{l}\text { sport part. } \\
\mathrm{N}=4042\end{array}$ & $\begin{array}{l}\text { non-part. } \\
N=1552\end{array}$ & $\begin{array}{l}\text { sport part. } \\
\mathrm{N}=1256\end{array}$ & $\begin{array}{l}\text { non-part. } \\
\mathrm{N}=394\end{array}$ & $\begin{array}{l}\text { sport part } \\
\mathrm{N}=402\end{array}$ & $\begin{array}{l}\text { non-part. } \\
\mathrm{N}=1355\end{array}$ & $\begin{array}{l}\text { sport part. } \\
\mathrm{N}=1557\end{array}$ & $\begin{array}{l}\text { non-part. } \\
\mathrm{N}=2129\end{array}$ & $\begin{array}{l}\text { sport part. } \\
\mathrm{N}=1306\end{array}$ & $\begin{array}{l}\text { non-part. } \\
\mathrm{N}=1004\end{array}$ & $\begin{array}{l}\text { sport part. } \\
\mathrm{N}=307\end{array}$ \\
\hline inner harmony & 2023,53 & 2018,02 & 1403,58 & 1395,48 & 388,55 & 408,26 & 1453,82 & 1458,83 & 1702,81 & 1737,46 & 643,66 & $696,36 * *$ \\
\hline power & 1982,64 & $2101,59 * *$ & 1368,57 & $1439,63 *$ & 398,55 & 398,45 & 1452,24 & 1460,21 & 1701,54 & 1739,54 & 645,40 & 690,68 \\
\hline freedom & 1995,33 & $2104,25 * *$ & 1379,46 & 1425,90 & 387,69 & 409,09 & 1445,95 & $1465,68^{*}$ & 1680,52 & $1773,73 * *$ & 650,73 & 673,22 \\
\hline social order & 1979,18 & 1999,00 & 1373,08 & $1433,94 *$ & 388,45 & 408,35 & 1421,74 & $1486,75^{* *}$ & 1690,45 & $1757,57 *$ & 658,30 & 648,49 \\
\hline interesting life & 1951,99 & $2163,22 * * *$ & 1340,33 & $1475,24 * * *$ & 383,25 & $413,45^{*}$ & 1405,06 & 1501,27 & 1658,59 & $1809,41 * * *$ & 640,02 & $708,27 * *$ \\
\hline wealth & $2068,30 *$ & 1984,59 & 1393,83 & 1407,77 & 393,33 & 403,57 & 1455,84 & 1457,07 & $1750,96 * *$ & 1659,11 & 657,06 & 652,54 \\
\hline national identity & 1915,93 & $2070,56 * * *$ & 1335,40 & $1481,45^{* * *}$ & 380,35 & 416,29 & 1397,71 & $1507,66 * * *$ & 1655,62 & $1814,25 * * *$ & 642,29 & $700,85 *$ \\
\hline creativity & 1890,54 & $2102,07 * * *$ & 1357,38 & $1453,74 * *$ & 377,90 & $418,69 * *$ & 1400,95 & $1504,84 * * *$ & 1655,74 & $1814,05 * * *$ & 631,70 & $735,47 * * *$ \\
\hline peace & 2042,24 & 2030,77 & 1409,62 & 1398,18 & 394,44 & 404,12 & 1436,85 & 1461,32 & 1711,07 & 1729,30 & 650,47 & 663,22 \\
\hline tradition & 1964,96 & 1998,62 & 1367,71 & $1449,96 * *$ & 384,60 & 413,11 & 1416,03 & $1479,24 *$ & 1681,98 & $1776,72 * *$ & 642,23 & $689,71 *$ \\
\hline religion & 2005,26 & 2062,72 & 1386,30 & 1426,99 & 397,09 & 401,71 & 1401,13 & $1492,06 * *$ & 1706,14 & 1737,33 & 665,45 & 615,09 \\
\hline family safety & 2029,97 & 2061,24 & 1398,06 & 1412,46 & 387,00 & 410,92 & 1423,25 & $1473,03 *$ & 1704,59 & 1739,86 & 648,70 & 668,92 \\
\hline diverse life & 1961,75 & $2153,18 * * *$ & 1359,99 & $1459,50 * *$ & 378,36 & $418,81 * *$ & 1404,81 & $1488,89 * *$ & 1670,14 & $1796,02 * * *$ & 633,30 & $718,41 * * *$ \\
\hline true friendship & 1965,48 & $2164,64 * * *$ & 1369,52 & $1447,72 * * *$ & 387,66 & 410,32 & 1417,14 & $1478,28 * *$ & 1681,34 & $1777,77 * * *$ & 635,44 & $711,53 * * *$ \\
\hline love & 1997,82 & 2044,15 & 1375,48 & $1440,36 *$ & 384,00 & 413,66 & 1417,41 & $1478,05^{*}$ & 1681,31 & $1777,81 * *$ & 646,95 & 674,53 \\
\hline beauty & 2020,22 & 2064,42 & 1411,02 & 1396,45 & 394,92 & 403,69 & 1440,40 & 1458,26 & 1714,61 & 1723,52 & 645,98 & 677,67 \\
\hline courtesy & 1999,26 & $2081,40 *$ & 1375,06 & $1431,45^{*}$ & 389,53 & 407,30 & 1446,75 & 1464,98 & 1673,45 & $1785,24 * * *$ & 650,48 & 674,06 \\
\hline unity with nature & 1943,49 & $2077,25 * * *$ & 1357,13 & $1463,03 * *$ & 375,78 & $421,18 * *$ & 1374,80 & $1514,73 * * *$ & 1661,69 & $1809,80 * * *$ & 639,31 & $699,10 * *$ \\
\hline decision-making rights & 1926,49 & $2137,47 * * *$ & 1357,17 & $1462,98 * * *$ & 390,53 & 407,70 & 1416,49 & $1478,84^{*}$ & 1673,81 & $1790,04 * * *$ & 634,15 & $715,68 * *$ \\
\hline
\end{tabular}

$* \mathrm{p}<0.05 ; * * \mathrm{p}<0.01, * * * \mathrm{p}<0.001$ 
In summary, findings of this study revealed substantial differences between the sport participant and the non-participant sub-groups, which were reflected by results gained from the strength of consideration given to the values, but not from the hierarchical order of values. In the strength of consideration given to each of the specific values, the results of the Mann \& Whitney $U$ test showed significant differences between the two sub-groups. Subjects participating in regular sporting activity valued 'true friendship', 'creativity', 'interesting and diverse life' significantly higher than the nonparticipant subjects, as was also found in 2000 (Perényi 2008). These findings also support the results of previous research conducted with smaller, non-representative Hungarian samples in the same age groups and state that youth participating in regular sporting activities value friendship significantly higher (Pluhár et al 2003); they are also more open to change, accept others more easily and are able to adapt to changing circumstances better than their non-active peers (Aszmann 1997).

Furthermore, in comparison to the results from the turn of the millennium, in this sample it was found that more priority was given by sport participants to values of 'unity with nature' and 'decisionmaking rights'. These values represent the values of independent thinking, self-conscious decisions that were, amongst others, also reinforced by the political-economic changes characteristic of former state-socialist countries (Schwartz and Bardi 1997). However, the higher importance given to the materialistic value of 'wealth/richness' by the non-participants in the first set of data (Perényi 2008), was not traceable four years later. The sport participants and the non-participants in general, did not differ in their preference for this value. This change can mostly be explained by the moderate economic progress of the country, resulting in less preference for materialistic values on the societal level (Bauer and Szabó 2005, Inglehart 1991). These results are mostly maintained as the demographic variables were considered in the analysis.

Also, along some of the ranges of the socio-demographic variables, the preference of 'tradition', 'power', and 'national identity' was recorded. An example would be the value of 'tradition' which shows a strong connection to the size of residential an area where people live. Places with a smaller number of inhabitants show higher priorities for traditional values (Bauer 2002), and during the examined period the democratisation of sport allowed an enhanced level of participation in small villages (by 11\%) and towns (by 8\%). Having a larger proportion of sport participants from this area in the sample may increase statistical preferences, for example for the value of 'tradition'. In the case of 'power' a similar procedure may have shaped results, but in connection to education, as sport participants with a lower education level may use sport as an outlet to fulfil their need for power. The change in the priority given by sport participants to the value of 'national identity' during the interval between the two sets of data may also be attached to the aforementioned democratisation of sports; however, this connection needs special attention in forthcoming analysis.

In some instances, other values also showed a difference between the two sub-groups along some of the socio-demographic variables, such as 'beauty', 'religion'; however, these values were very low in the order of the values, meaning that neither the sport participant nor the non-active group considered them in the focus of their value structure.

\section{Conclusions}

Youth research series of Hungary provides a unique opportunity, among other life aspects of youth, to analyse the trends of sport participation in connection to core human values, and to draw conclusions on a broader societal level. Our findings reinforce the importance of sport participation, not only as a token for the general physical health of youth and future generations, but also as a fundamental element of youth socialisation and value transfer. 
An association is suggested by the findings between the preferences of specific values and sporting activities. The majority of values associated with sport participation fall under the selfdirection, stimulation value dimensions by Schwartz (1994) in positive associations, and under power values in negative associations. The dynamics of materialistic values outlined by Inglehart (1997) may be balanced by the value environment of sport and could supply value stability during times of societal transition. Furthermore, the continuing democratisation of society and sport, as one of the societal institutions, provided for the inclusion of wider societal segments, which can also be tracked by the wider portfolio of preferred values by sport participants. Also, some values like appreciation of 'tradition' and 'national identity' may have more association to other socio-demographic factors and, as a consequence, to life circumstances, such as size of settlement or level of education.

Schwartz (1994) also emphasizes the reverse transformational effect of human values and of the surrounding environment. Consequently, consideration of values by individuals is not only determined by socio-demographic status and life circumstances, but values can also be accepted by individuals in order for them to gain social inclusion to groups. This may be a conscious decision in the case of sport. It must be stated, however, that participation in sports alone cannot be the cause of the differences found in a subject's value-preferences. Value transfer is a complex procedure; it does not happen in separation from other socialising agents and platforms. Also, in the case of sport, it may well be that youngsters having higher preferences on the particular values connected to sport choose to participate in order to seek true realization of those values through sports.

Further investigation is needed in order to find out what may cause the growth of importance allocated to sport related values, whether it is the participation in sporting activity itself, or whether it is gender, education, or the characteristics of a specific life period. The education level and labour market activity necessitates raising such questions, since both values and sport participation correspond with level of education and activities of different life stages. Also, further analysis of value change during the interval between the two sets of data could give more explanation for having new values connected to sport participation outside of the self-direction and openness-to-change dimension. Finding such answers would be outside the methodology of this present study; other multidimensional statistical analyses shall be used, such as factor and regression analyses. Furthermore, a qualitative approach could be undertaken to give more clarity to meanings behind human values. This prospective for the evaluation of the data will be concluded and published in the near future.

\section{REFERENCES}

Andorka, R. (2000). Bevezetés a Szociológiába. Budapest: Osiris.

Aszmann, A. (1997). Iskolás Gyerekek Egészségmagatartása 1986-1993. Budapest: Anonymus Kiadó.

Bauer, B. (2002). Az Ifjúság Viszonya az Értékek Világához. In A. Szabó, B. Bauer and L. Laki (Eds.): Ifjúság2000 ${ }^{\odot}$ Tanulmányok I., pp. 202-19. Budapest: N.mzeti Ifjúságkutató Intézet.

Bauer, B., Szabó, A (2005). Gyorsjelentés Ifjúság2004 ${ }^{\circledR}$, pp. 81-86 and pp. 55-58. Budapest: Nemzeti Ifjúságkutató Intézet.

Bourdieu, P. (1978). Sport and Social Class. Social Science Information, 17(6), pp. 819-840.

Bourdieu, P. (1984). Distinction: Social Critique of the Judgement of Taste. Cambridge, MA: Harvard University Press.

Bredemeier, B., Schilds, D. (1993). Moral Psychology in the Context of Sport. In R. N. Singer, M. Murphy \& Tennant, L. Keith (Eds.): Handbook of Research on Sport Psychology, pp. 587-599. New York: Macmillan. 
Coakley, J. (1993). Socialisation and Sport. In R.N. Singer, M. Murphy, L.K., Tennant (Eds.) Handbook of Research on Sport Psychology, pp. 571-586. New York: Macmillan.

Deci, E.L., Flaste, R. (1995). Why we Do What we Do, Understanding Self-motivation. New York: Penguin Books.

Dubois, P.E. (1986). The Effect of Participation in Sport on Value Orientations of Young Athletes. Sociology of Sport Journal, 3, pp. 29-42.

Fábri, I. (2002). A Sport, mint a Fiatal Korosztályok Életmódjának Meghatározó Eleme. In A. Szabó, B. Bauer and L. Laki (Eds.) Ifjúság2000 ${ }^{\circ}$ Tanulmányok I., pp. 166-79. Budapest: Nemzeti Ifjúságkutató Intézet.

Gáldi, G. (2002). Fizikai aktivitás Magyarországon az Ezredfordulón. Magyar Spottudományi Szemle, 3-4, pp. 16-18.

Giddens, A. (2000). Szociológia. Osiris, Budapest.

Hartmann-Tews, I. (2006). Social Stratification in Sport and Sport Policy in the European Union. European Journal for Sport and Society, 3(2), pp. 109-124.

Inglehart, R. (1991). Cultural Change in Advanced Industrial Societies. Priceton, NJ: Priceton University Press.

Inglehart, R. (1977). The Silent Revolution. New Jersey, Princeton.

Inglehart, R. (1997). Modernization and Postmodernization. Princetown, NJ: Princetown University Press.

Mielke, R., Bahlke, S. (1995). Structure and Preferences of Fundamental Values of Young Athletes Do they Differ from Non-Athletes and from Young People with Alternative Leisure Activities? International Review for the Sociology of Sport, 1(30), pp. 419-436.

Perényi, S. (2005). Transmission of Sporting Values via Sport Participation of Hungarian University Students. In S.Gy. Földesi and A. Gál (Eds.). Sports and Society: Social Conditions in Sports. Hungarian Society for Sport Sciences.

Perényi, S. (2008). Sporttevékenység és az Értékorientáció Összefüggései Fiataloknál. Új Ifjúsági Szemle, 6(4), pp. 71-84.

Perényi, S. (Spring 2010). On the Fields, in the Stands, in front of TV - Value Orientation of Youth Based on Participation in and Consumption of Sports. European Journal for Sport and Society.

Perkins, D.F., Jacobs, J.E., Barber, B.L., \& Eccles, J.S. (2004). Childhood and Adolescent sport participation in sports and Physical Fitness Activities during Young Adulthood. Youth and Society, 35(4), pp. 495-520.

Pluhár S., Keresztes N., Pikó B. (2003). Ép Testben Ép Lélek, Középiskolások Értékrendje Fizikai Aktivitásuk Tükrében. Magyar Spottudományi Szemle, 2, 29-33.

Scheerder, J., Vanreusel, B., \& Taks, M. (2005). Stratification Patterns of Active Sport Involvement among Adults, Social Change and Persistence. International Review for the Sociology of Sport, 40/2, pp. 139-162.

Schwatrz, S.H. (1992). Universals in the Content and Structure of Values: Theory and Empirical Test in 20 Countries. In M. Zanna (Eds.) Advances in Experimental Social Psyhology, 25, pp. 1-65. New York: Academic Press.

Schwartz, S.H. (1994). Are there Universal Aspects in the Content and Structure of Values? Journal of Social Issues, 50, pp. 19-45.

Schwartz, S.H. \& Bardi, A. (1997). Influences of Adaptation to Communist Rule on Value Priorities in Eastern Europe. Political Psychology, 18(2), pp. 385-410.

Skille, E.A. (2005), Individuality or Cultural Reproduction? ,Adolescents' Sport Participation in Norway: Alternative versus Conventional Sports. International Review for the Sociology of Sport, 40(3), pp. 307-320.

Stempel, C. (2005). Adult Participation Sports as Cultural Capital, A Test of Bourdieu's Theory of the Field of Sports. International Review for the Sociology of Sport, 40/4, pp. 411-432.

Tenenbaum. G., Driscoll, M. (2005). Methods of Research in Sport Sciences. Quantitative and Qualitative Approaches. Meyer \& Meyer Sports, UK.

Vanreusel, B., Renson, R., Beunen, G., Claessens, A.L., Johan Lefevre, J., Lysens, R., and Vanden Eynde, B. (1993). A Longitudinal Study of Youth Sport Participation and Adherence to Sport in Adulthood. International Review for the Sociology of Sport, 32, pp. 373-387. 
White, P. \& Wilson, B. (1999). Distinction in the Stands. International Review for the Sociology of Sport, 34(3), pp. 245-264.

Wilson, T.C. (2002). The Paradox of Social Class and Sports Involvement, The Roles of Cultural and Economic Capital. International Review for the Sociology of Sport, 37/1, pp. 5-16. 